\title{
Pengaruh Arang Cangkang Kelapa Sawit Sebagai Pengganti Filler Aspal Penetrasi 60/70
}

\author{
Sartika Nisumanti ${ }^{1)}$, Muhmaad Yusuf $^{2)}$ \\ ${ }^{112)}$ Program Studi Teknik Sipil, Universitas Indo Global Mandiri, \\ Jl. Jend. Sudirman No. 629 Km. 4 Palembang Kode Pos 20129 \\ Email : sartika.nisumanti@uigm.ac.id ${ }^{1)}$, Yusuf22021998@gmail.com ${ }^{2)}$
}

\begin{abstract}
Asphalt as a binding material in the composition of road pavement is one of the most important materials, although the amount needed is only $4-10 \%$ of other material. Asphalt has elastic properties when loaded by vehicle and has a fairly good resistance. In this research, asphalt used is asphalt pen (60/70) because it is suitable with climatic conditions in Indonesia. Fillers, generally consisting from stone ash, limestone and cementland portland, or other nonplastic materials. One of the compotition in asphalt concrete is cement, In this time cement has been used as a filler. The purpose of this reseach is to known the influenced of the palm shell charcoal for the stability of 60/70 penetration asphalt and whether shell charcoal filler can be used on road pavement mixtures. From the marshall test results obtained the stability value for asphalt with a palm oil shell charcoal concentration of 3.5\% by 1375.6, a 4\% content with a value of 1566.6, and a 4.5\% concentration decreased to 1138.9. Marshall test results show a stability value greater than conventional asphalt 1341.6 and exceeds the specification limit $>800 \mathrm{~kg} / \mathrm{mm}$. While the use of asphalt with oil palm shell charcoal filler values VIM, flow, and FVB did not fulfill in specification limits so it cannot be used to replacement as filler material in asphalt concrete mixtures. It cause if the flow value is low, the mixture is very likely to experience cracks, as well as the VIM value, if it is too small, it will cause cavity damage in the mixture so that the asphalt becomeshave permeability and brittle. Low FVB value will cause the mixture being porous.
\end{abstract}

Keywords : Asphalt, Filler, Marshall Test

\begin{abstract}
ABSTRAK
Aspal sebagai bahan pengikat pada struktur pekerasan jalan merupakan salah satu material yang sangat penting, meskipun jumlah yang dibutuhkan hanya 4-10\% dari aggregat lain. Aspal memiliki sifat elastis bila menerima beban kendaraan dan memiliki ketahanan yang cukup kuat. Dalam penelitian ini Aspal yang dipakai adalah aspal pen (60/70) karena disesuaikan dengan kondisi iklim di Indonesia. Bahan pengisi atau filler, umumnya terdiri dari abu batu, kapur dan sement portland, atau bahan non plastis lainnya. Salah satu campuran pada lapis aspal beton adalah semen sebagai filler, saat ini semen sudah banyak digunakan sebagai filler. Tujuan Penelitian ini mengetahui berapa besar perngaruh arang cangkang kelapa sawit terhadap stabilitas aspal penetrasi 60/70 serta apakah aspal dengan filler arang cangkang kelapa sawit dapat digunakan pada campuran perkerasan jalan. Dari hasil pengujian marshall diperoleh nilai stabilitas untuk aspal dengan kadar arang cangkang kelapa sawit 3,5\% sebesar 1375,6, kadar 4\% dengan nilai 1566,6, dan kadar 4,5\% menurun menjadi 1138,9. Hasil marshall test menunjukkan nilai stabilitas lebih besar dari aspal konvensional 1341,6 dan melebihi batas spesifikasi $\geq 800 \mathrm{~kg} / \mathrm{mm}$. Sementara penggunaan aspal dengan filler arang cangkang kelapa sawit mendapatkan nilai VIM, flow, dan FVB tidak memenuhi batas spesifikasi sehingga tidak dapat digunakan untuk bahan pengganti filler pada campuran aspal beton. Hal ini dikarenakan jika nilai flow rendah maka campuran sangat berpontensi mengalami keretakan, begitu juga dengan nilai VIM, bila terlalu kecil maka akan menyebabkan terjadinya kerusakan rongga didalam campuran sehingga membuat aspal menjadi kedap air dan getas. Nilai FVB yang rendah akan mengakibatkan campuran bersifat porous.
\end{abstract}

Kata kunci : Aspal, Filler, Uji Marshall 


\section{Pendahuluan}

Jalan mempunyai peran yang sangat strategis dalam bidang sosial, ekonomi, budaya dan hankam, akan tetapi seiring dengan waktu kinerja perkerasan mengalami penurunan tingkat pelayanan akibat beban lalu lintas dan lingkungan. Untuk memperoleh kinerja perkerasan yang layak dan sesuai dengan tuntutan pengguna jalan cukup sulit dicapai. Salah satu sebabnya kerusakan jalan umumnya adalah tanah dasar (subgrade), kualitas material, dan pelaksanaan pekerjaan di lapangan.

Selain itu permasalahan terhadap durabilitas suatu lapisan perkerasan umumnya berkaitan dengan seberapa lama konstruksi perkerasan mampu menjalankan fungsinya tanpa mengalami kerusakan yang fatal. Penyebab menurunya tingkat keawetan biasanya adalah volume lalu lintas dan air. Permasalahan yang berhubungan dengan keawetan campuran aspal.

Aspal sebagai bahan pengikat pada struktur pekerasan jalan merupakan salah satu material yang sangat penting, meskipun jumlah yang dibutuhkan hanya $4-10 \%$ dari aggregat lain. Aspal memiliki sifat elastis bila menerima beban kendaraan, dan memiliki ketahanan yang cukup kuat. Selain itu sebagai lapis penutup perkerasan untuk menunjang kelancaran transportasi, harus menciptakan rasa nyaman dan aman bagi para pengguna jalan. Dalam penelitian ini Aspal yang dipakai adalah aspal pen (60/70) karena disesuaikan dengan kondisi iklim di Indonesia dan sering digunakan pada pembuatan perkerasan jalan.

Bahan pengisi atau filler, umumnya terdiri dari abu batu, kapur dan sement portland, atau bahan non plastis lainnya. Salah satu campuran pada lapis aspal beton adalah semen sebagai filler, kini semen sudah banyak digunakan sebagai filler dan harga semen cukup mahal, Oleh karena itu pemanfaatan secara optimal arang cangkang kelapa sawit sebagai bahan pengganti filler pada perkerasan lapis aspal beton (LASTON).

Metode yang digunakan adalah melakukan percobaan di laboratorium dengan melakukan perencanaan campuran.

Penelitian ini bertujuan untuk mengetahui berapa besar perngaruh arang cangkang kelapa sawit terhadap stabilitas aspal penetrasi 60/70 serta apakah aspal dengan filler arang cangkang kelapa sawit dapat digunakan pada perkerasan jalan.

Arang cangkang kelapa sawit harganya jauh lebih murah jika dibandingkan dengan harga semen, sehingga sangat ekonomis jika digunakan sebanyak mungkin sebagai bahan filler pengganti di dalam campuran aspal. Sehingga perlu dilakukan penelitian mengenai arang cangkang kelapa sawit sebagai pengganti filler pada campuran aspal. Diharapkan hasil penelitian ini dapat digunakan sebagai filler yang memenuhi batas spesifikasi dan meningkatkan stabilitas kinerja perkerasan jalan. Disamping itu juga agar memiliki nilai guna, sehingga dapat mengurangi jumlah limbah yang di akibatkan oleh cangkang kelapa sawit dapat berkurang.

\section{A. Perkerasan Jalan}

Menurut Sukirman (2003), perkerasan jalan merupakan lapisan perkerasan yang terletak di antara lapisan tanah dasar dan roda kendaraan yang berfungsi memberikan pelayanan kepada transportasi.

Penggunaan bahan pengganti pada campuran aspal beton dengan tujuan untuk mendapatkan kinerja campuran yang baik dan ekonomis. Salah satu campuran pada lapis aspal beton adalah semen, kini semen sudah sangat banyak digunakan sebagai filler dan harga semen sendiri terbilang cukup mahal, sehingga pada penelitian ini di coba untuk menggunakan arang cangkang kelapa sawit sebagai pengganti semen pada filler perkerasan lapis aspal beton (LASTON) diharapkan hasil penelitian ini dapat digunakan sebagai filler disamping itu juga agar memiliki nilai guna, sehingga dapat mengurangi jumlah limbah yang di akibatkan oleh cangkang kelapa sawit dapat berkurang.

\section{B. Perkerasan Lentur (flexible pavement)}

Perkerasan lentur adalah jenis perkerasan yang menggunakan aspal sebagai bahan pengikat untuk lapisan perkerasan. Konstruksi perkerasan lentur terdiri dari lapisan-lapisan yang diletakkan diatas tanah dasar yang telah dipadatkan. Lapisan-lapisan tersebut berfungsi sebagai penerima beban lalu lintas dan menyebarkan ke lapisan dibawahnya.

\section{Perkerasan Kaku (rigid pavement)}

Perkerasan kaku adalah jenis perkerasan yang menggunakan lapisan pelat beton baik menggunakan tulangan atau tanpa tulangan yang diletakkan di atas tanah dasar dengan atau tanpa pondasi bawah. Beban yang bekerja atau yang melintasi lapisan perkerasan kaku sebagian besar dipikul oleh pelat beton tersebut.

\section{Perkerasan Komposit (composite pavement)}

Perkerasan komposit adalah kombinasi antara konstruksi perkerasanlentur dengan konstruksi perkerasan kaku. Dalam kombinasi tersebut, perkerasan kaku dapat diletakkan di atas perkerasan lentur atau juga sebaliknya.

\section{E. Aspal}

Aspal sebagai bahan pengikat dalam perkerasan jalan merupakan gugusan hidrokarbon yang terdiri dari campuran mineral dan bitumen yang terjadi melalui proses alam yang diperoleh dari residu penyulingan minyak bumi. Jenis - jenis aspal beton :

1. Asphalt Concrete - Wearing Course (AC-WC)

Asphalt Concrete -Wearing Course (AC-WC) merupakan lapisan perkerasan yang terletak paling atas dan berfungsi sebagai lapisan aus.

2. Asphalt Concrete - Binder Course (AC-BC)

Lapisan ini merupakan lapisan perkerasan yang terletak dibawah lapisan aus (wearing course) dan di atas lapisan pondasi (base course)

3. Asphalt Concrete - Base (AC-Base)

Laston Atas atau lapisan pondasi atas (AC- Base) merupakan pondasi perkerasan yang terdiri dari 
campuran agregat dan aspal dengan perbandingan tertentu dicampur dan dipadatkan dalam keadaan panas.

Laston adalah suatu lapis permukaan yang terdiri dari campuran laston keras dan agregat yang bergradasi menerus, laston bersifat kedap air, mempunyai nilai struktural, awet. Setiawan AD, (2003)

\section{F. Karakteristik Campuran Beraspal}

Susilo Joko (2010 ) Menyatakan karakteristik campuran aspal yang harus dimiliki oleh beton aspal adalah stabilitas, keawetan atau durabilitas, kelenturan atau fleksibilitas, ketahanan terhadap kelelahan (fatique risistance), kekesatan permukaan atau ketahanan geser, kedap air, dan kemudahan pelaksanaan (workability).

\section{G. Agregat}

Wahyudi (2010) Agregat adalah partikel mineral yang berbentuk butiran-butiran yang merupakan salah satu penggunaan dalam kombinasi dengan berbagai macam tipe mulai dari sebagai bahan material di semen untuk membentuk beton, lapis pondasi jalan, material pengisi, dan lain-lain. Material agregat yang digunakan untuk konstruksi perkerasan jalan berfungsi untuk menahan beban lalu lintas. Agar dapat digunakan sebagai campuran aspal, agregat harus lolos dari berbagai uji yang telah ditentukan. Banyaknya agregat dalam campuran aspal pada umumnya berkisar antara 90\% hingga $95 \%$ terhadap total berat campuran atau $70 \%$ hingga $85 \%$ terhadap volume campuran aspal.

\section{H. Agregat kasar}

Menurut SNI 1970-2008 Fraksi agregat kasar untuk rancangan campuran adalah yang tertahan ayakan No.8 $(2,36 \mathrm{~mm})$ yang dilakukan secara basah dan harus bersih, keras, awet, dan bebas dari lempung atau bahan yang tidak dikehendaki lainnya dan memenuhi ketentuan. Agregat yang digunakan dalam lapisan perkerasan jalan ini adalah agregat yang memiliki diameter agregat antara 2,36 mm sampai $19 \mathrm{~mm}$.

\section{Agregat halus}

Berdasarkan SNI 03-6820-2002 Agregat halus adalah material yang lolos saringan no.8 $(2,36 \mathrm{~mm})$ dan tertahan saringan no.200 $(0,075 \mathrm{~mm})$.

\section{J. Filler (Bahan Pengisi)}

Bahan Pengisi (filler) berfungsi sebagai pengisi rongga udara pada material sehingga memperkaku lapisan aspal. Bahan yang sering digunakan sebagi filler adalah fly ash, abu sekam, debu batu kapur, dan semen Portland.

Fungsi filler sebagai pengisi antara agregat yang lebih kasar, sehingga rongga udara menjadi lebih kecil dan menghasilkan tahanan gesek serta penguncian antar butir yang tinggi, sehingga akan meningkatkan stabilitas campuran. Bila digunakan pada campuran laston, filler akan berbentuk mastik yang akan bersama-sama akan mengikat partikel agregat, kekuatan pada laston akan bertambah dengan adanya campuran ini.
Filler yang digunakan pada penelitian ini adalah arang cangkang kelapa sawit. Dimana pada Cangkang kelapa sawit mengandung zat lignin, hemiselulosa, selulosa, air, abu dan komponen ekstraktif dimana seluruh senyawa ini termasuk dalam senyawa hidrokarbon. Zat lignin, hemiselulosa, dan selulosa merupakan zat yang keras, lengket, kaku, dan mudah mengalami oksidasi. (Hardiyatmo, 2007)

\section{K. Pengujian Marshall}

Nilai rongga campuran aspal dapat meningkat apabila meningkatkan proporsi agregat kasar dan mengurangi proporsi agregat halus [4]. Stabilitas Marshall campuran aspal porus lebih rendah dari beton aspal yang menggunakan gradasi rapat, namun meningkat bila menggunakan gradasi terbuka dan fraksi halusnya diperbanyak

\section{Berat Jenis}

1. Berat jenis bulk agregat

Berat jenis bulk adalah perbandingan antara berat bahan di udara pada satuan volume dan suhu tertentu dengan berat air suling serta volume yang sama pada suhu tertentu pula.

$$
G_{s b}=\frac{P_{1}+P_{2}+\ldots \ldots \ldots+P_{n}}{\frac{P_{1}}{G_{2}}+\frac{P_{2}}{G_{2}} \ldots \ldots \ldots+\frac{P_{n}}{G_{n}}}
$$

\section{Penyerapan Aspal}

Penyerapan aspal dinyatakan dalam persen terhadap berat agregat total tidak terhadap campuran.

$$
P_{b a}=100 x \frac{G_{s e}-G_{s b}}{G_{s b} x G_{s e}} x G_{b}
$$

\section{N. Kadar Aspal Efektif}

$$
P_{b e}=P_{b} x \frac{b a}{100} x P_{s}
$$

\section{O. Rongga di antara Mineral Agregat (VMA)}

Rongga di antara mineral agregat (VMA) adalah ruang diantara partikel agregat pada suatu perkerasan beraspal, termasuk rongga udara dan volume aspal efektif (tidak termasuk volume aspal yang diserap agregat).

VMA terhadap campuran total:

$$
V M A=100 x \frac{G_{m b} x P_{s}}{G_{s b}}
$$

\section{P. Rongga di dalam Campuran (VIM)}

Rongga di dalam campuran atau VIM dalam campuran perkerasan beraspal terdiri atas ruang udara di antara pertikel agregat yang terselimuti aspal.

$$
V I M=100 x \frac{G_{m m} x G_{m b}}{G_{m m}}
$$




\section{Q. Stabilitas}

Stabilitas adalah kemampuan campuran aspal untuk menahan deformasi akibat beban yang bekerja tanpa mengalami deformasi permanen seperti gelombang, alur ataupun bleeding yang dinyatakan dalam satuan $\mathrm{kg}$ atau lb. Nilai stabilitas diperoleh dari nilai yang ditunjukkan oleh jarum dial pada alat uji. Nilai yang ditunjukkan pada jarum dial perlu dikonversikan terhadap alat Marshal, Mudianto (2004).

\section{R. Kelelehan (Flow)}

Nilai flow diperoleh dari nilai yang ditunjukkan oleh jarum dial. Nilai yang ditunjukkan pada jarum dial tidak perlu dikonversikan terhadap alat Marshall karena satuannya nilainya sudah dalam millimeter $(\mathrm{mm})$.

Parameter flow diperlukan untuk mengetahui deformasi vertikal campuran saat dibebani hingga hancur (pada stabilitas maksimum). Flow akan meningkat seiring dengan meningkatnya kadar aspal. (SNI-06-2489-1991)

\section{S. Hasil Bagi Marshall (MQ)}

Marshall Quotient (MQ) merupakan hasil pembagian dari stabilitas dengan kelelehan. Marshall Quotient (MQ) yaitu hasil bagi stabilitas dan flow, yang digunakan sebagai indikator kelenturan yang potensial terhadap keretakan. Nilai Marshall Quotient dinyatakan dalam kg/mm. (Hardiyatmo,H.C, 2007).

$$
\text { Marshall Quotient }(M Q)=\frac{\text { stabilitas }}{\text { flow }}
$$

\section{T. Metode Penelitian}

Tahap pengujian ini digunakan aspal penetrasi 60/70 sebagai campuran laston AC-WC meliputi

1. Penyediaan alat dan bahan yang akan digunakan

2. Pengujian agregat

a. Pengujian analisa saringan agregat berdasarkan SNI 0 -1968-1990.

b. Berat jenis dan penyerapan berdasarkan SNI- 0 1968-1990

c. Pengujian berat isi agregat SNI 0 -1968-1990

d. Pengujian abrasi menggunakan mesin los angeles berdasarka SNI 0 -1968-1990

U. Pengujian Aspal

1. Pengujian Titik Lembek Aspal Berdasarkan SNI 062434-1991.

2. Pengujian Titik Nyala dan Titik Bakar Berdasarkan SNI 06-2433-1991.

3. Pengujian Daktilitas Berdasarkan SNI-06-2434-1991

4. Pengujian Penetrasi Berdasarkan SNI 06-2456-1991

V. Pembuatan Benda Uji

Pembuatan benda uji yang dibuat dalam penelitian ini terdiri

15 benda uji dan setiap benda uji diberikan kadar aspal; 4,5\%, $5,0 \%, 5,5 \% \mathrm{~m} 6,0 \%, 6,5 \%$.

Sedangakan benda uji aspal dengan arang cangkang sawit kadar aspal yang berbeda-beda dari 3,5\% ; 4\% ; 4,5\% .

1. Pembuatan Benda Uji Aspal Konvensional

\begin{tabular}{|c|c|c|c|}
\hline No & Kadar Aspal & $\begin{array}{c}\text { Kadar Filler ( } \\
\text { Semen ) }\end{array}$ & $\begin{array}{c}\text { Jumlah } \\
\text { Benda Uji } \\
\text { (Buah) }\end{array}$ \\
\hline 1 & $4,5 \%$ & $2 \%$ & 3 \\
\hline 2 & $5,0 \%$ & $2 \%$ & 3 \\
\hline 3 & $5,5 \%$ & $2 \%$ & 3 \\
\hline 4 & $6,0 \%$ & $2 \%$ & 3 \\
\hline 5 & $6,5 \%$ & $2 \%$ & 3 \\
\hline & Total & & 15 \\
\hline
\end{tabular}

Sumber : Hasil Pengujian 2019

2. Pembuatan Benda Uji Aspal Dengan Arang Cangkang Kelapa Sawit

\begin{tabular}{|c|c|c|c|}
\hline No & Kadar Aspal & $\begin{array}{c}\text { Kadar Arang } \\
\text { Cangkang } \\
\text { Kelapa Sawit }\end{array}$ & $\begin{array}{c}\text { Jumlah } \\
\text { Benda Uji } \\
\text { (Buah) }\end{array}$ \\
\hline 1 & $6 \%$ & $3,5 \%$ & 3 \\
\hline 2 & $6 \%$ & $4 \%$ & 3 \\
\hline 3 & $6 \%$ & $4,5 \%$ & 3 \\
\hline & Total & & 9 \\
\hline
\end{tabular}

3. Komposisi Campuran Pembuatan Benda Uji Aspal Konvensional.

\section{W. Pengujian Marshall}

Pengujian benda uji Marshall dengan tujuan mendapatkan sifat-sifat seperti : Stabilitas, Flow, VIM (Void In Mix), VFB (Void Filled With Bitumen), VMA (Void Mix Aggregate), dan Marshall Quotient (MQ).

\section{Pembahasan}

\section{A. Hasil pengujian aggregat}

Pengujian karakteristik agregat kasar, agregat halus dan filler dapat disimpulkan bahwa agregat yang digunakan untuk membuat campuran beraspal telah layak dan masih masuk spesifikasi Bina Marga 2010 Revisi 3.

Tabel 1. Hasil Pengujian Agregat

\begin{tabular}{|c|c|c|c|c|c|}
\hline \multicolumn{2}{|r|}{ Karakter } & \multirow{2}{*}{$\begin{array}{c}\text { Standar } \\
\text { Pengujian }\end{array}$} & \multirow[t]{2}{*}{ Spesifikasi } & \multicolumn{2}{|c|}{ Hasil } \\
\hline A & Agregat kasar & & & Split & Screen \\
\hline 1 & Berat Jenis Bulk & SNI -1969-1990 & $\operatorname{Min} 2,5$ & 2,54 & 2,53 \\
\hline 2 & Berat Jenis SSD & \begin{tabular}{|l} 
SNI-1969-1990 \\
\end{tabular} & 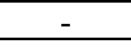 & 2,58 & 2,57 \\
\hline 3 & Berat Jenis Apparent & SNI-1969-1990 & - & 2,41 & 2,65 \\
\hline 4 & Penyerapan & SNI -1969-1990 & Maks 3\% & 2,41 & 1,9 \\
\hline 5 & AbrasiLos Angles & SNI 2417-2008 & Maks $40 \%$ & 37,99 & 37,99 \\
\hline 6 & $\begin{array}{l}\text { Kelekatan Agregat } \\
\text { Terhadap Aspal } \\
\end{array}$ & SNI 2439-2011 & $\operatorname{Min} 95 \%$ & 95 & 95 \\
\hline B & Agregat Halus & & & dust & Sand \\
\hline 1 & Berat Jenis Bulk & SNI 1970-2008 & $\operatorname{Min} 2,5$ & 2,51 & 2,51 \\
\hline 2 & Berat Jenis SSD & SNI 1970-2008 & - & 2,6 & 2,58 \\
\hline 3 & Berat Jenis Apparent & SNI 1970-2008 & - & 2,7 & 2,69 \\
\hline 4 & Penyerapan & \begin{tabular}{|l|} 
SNI 1970-2008 \\
\end{tabular} & Maks 3\% & 2,71 & 2,64 \\
\hline $\mathbf{C}$ & Filler & & & & \\
\hline 1 & Lolos Saringan No 200 & SNI 1969-2008 & $\operatorname{Min} 75 \%$ & & $\%$ \\
\hline 2 & Berat Jenis Filler & SNI 1969-2008 & - & & 5 \\
\hline
\end{tabular}

Sumber: Hasil Pengujian, 2019 


\section{B. Hasil Pengujian Aspal}

Aspal yang digunakan dalam campuran Laston (ACWC) menggunakan aspal penetrasi 60/70, kualifikasi layak. Hasil pengujian karakteristik aspal seperti pada tabel berikut:

Tabel 2. Hasil Pengujian Aspal

\begin{tabular}{|r|l|l|c|c|}
\hline No & \multicolumn{1}{|c|}{ Karakteristik } & Standar Pengujian & Spesifikasi & Hasil \\
\hline 1 & Berat jenis $\left(25^{\circ} \mathrm{C}\right)$ & SNI 06-2441-2011 & Min 1 & 1,035 \\
\hline 2 & Penetrasi $\left(25^{\circ} \mathrm{C}, 100 \mathrm{gr}, 5 \mathrm{dtl}\right)$ & SNI 06-2456-1991 & $60-70$ & 66 \\
\hline 3 & Titik lembek & SNI 06-2434-2011 & Min $48^{\circ} \mathrm{C}$ & $50^{\circ} \mathrm{C}$ \\
\hline 4 & Titik nyala & SNI 06-2433-2011 & Min $232^{\circ} \mathrm{C}$ & $310,5^{\circ} \mathrm{C}$ \\
\hline 5 & Titik bakar & SNI 06-2433-2011 & - & $315^{\circ} \mathrm{C}$ \\
\hline 6 & Daktalitas & SNI-06-2434-1991 & $100 \mathrm{~cm}$ & $>100 \mathrm{Cm}$ \\
\hline
\end{tabular}

Sumber: Hasil Pengujian, 2019

\section{Kadar Aspal Rencana (Desain Mix Formula)}

Kadar aspal rencana pada lapis AC-WC dilakukan perhitungan perkiraan nilai kadar aspal yang akan digunakan dalam menentukan kadar aspal optimum dan untuk kebutuhan pembuatan benda uji marshall, diperoleh $\mathrm{Pb}$ total 5,5\%.

\section{Komposisi Campuran}

Hasil perhitungan komposisi campuran mencukupi standar spesifikasi Bina Marga Revisi 3 dan dapat digunakan dalam pembuatan benda uji yang bertujuan untuk menentukan kadar aspal optimum, seperti pada gambar. Grafik gradasi campuran AC-WC.

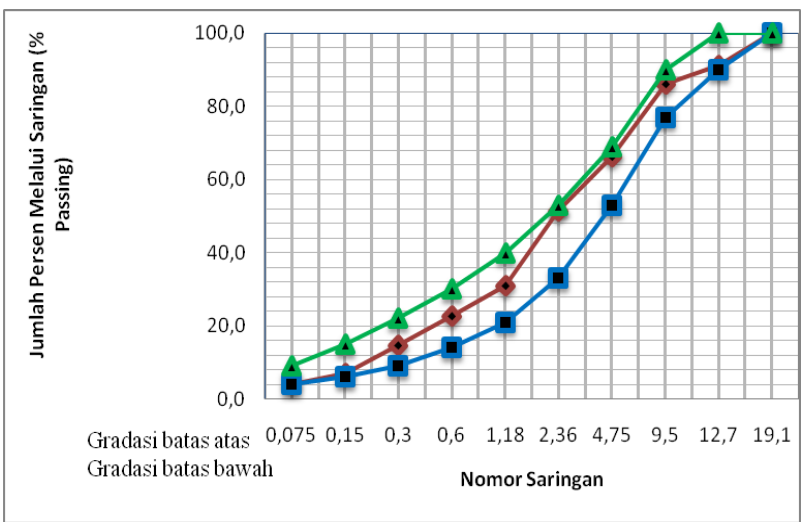

Dari gambar grafik diatas menunjukan dari gradasi batas atas dan gradasi batas bawah memenuhi spesifikasi Umum Bina Marga Revisi 3 dan dapat digunakan sebagai campuran aspal laston AC-WC.

\section{E. Pengujian Marshall Konvensional}

Pengujian marshall yang dilakukan untuk mendapatkan nilai kadar aspal optimum (KAO). Pengujian marshall dilakukann untuk mendapatkan hasil dari data berupa nilai VMA, VFA, VIM, Stabilitas, Flow dan Kepadatan. Pengujian marshall untuk menentukan kadar aspal KAO seperti pada tabel berikut.
Tabel 3. Hasil Marshall Konvensional

\begin{tabular}{|c|c|c|c|c|c|c|c|c|}
\hline No. & $\begin{array}{l}\text { Kadar } \\
\text { Aspal } \\
\mathbf{P b} \%\end{array}$ & $\begin{array}{c}\text { Kepadatan } \\
t / m^{3}\end{array}$ & $\begin{array}{l}\text { VIM } \\
3,0- \\
5,0 \%\end{array}$ & $\begin{array}{c}\text { VMA } \\
\text { Min }> \\
15 \%\end{array}$ & $\begin{array}{c}\text { VFA } \\
\text { Min }> \\
65 \%\end{array}$ & $\begin{array}{l}\text { Stabilitas } \\
\geq 800 \mathrm{~kg}\end{array}$ & $\begin{array}{c}\text { Flow } \\
2-4 \mathrm{~mm}\end{array}$ & $\begin{array}{c}\mathrm{MQ} \geq \\
250 \\
\mathrm{~kg} / \mathrm{mm}\end{array}$ \\
\hline 1. & 45 & 2,274 & 7,725 & 16,635 & 59,609 & 1193,7 & 2,60 & 459,12 \\
\hline 2. & 4,5 & 2,278 & 6,563 & 16,488 & 60,245 & 1285,4 & 2,70 & 476,08 \\
\hline 3. & 4,5 & 2,276 & 6,645 & 16,561 & 59,926 & 1256,5 & 2,80 & 448,76 \\
\hline \multicolumn{2}{|c|}{ Rata-rata } & 2,276 & 6,978 & 16,561 & 59,927 & 1245,2 & 2,70 & 461,32 \\
\hline 1 & 5,0 & 2,221 & 8,251 & 19,004 & 56,624 & 1261,5 & 3,83 & 445,76 \\
\hline 2 & 5,0 & 2,312 & 4,492 & 15,685 & 71,415 & 1311,6 & 2,85 & 460,23 \\
\hline 3 & 5,0 & 2,308 & 4,657 & 15,831 & 70,634 & 1180,5 & 2,9 & 407,06 \\
\hline \multicolumn{2}{|c|}{ Rata-rata } & 2,280 & 5,800 & 16,840 & 66,224 & 1251,2 & 3,19 & 437,683 \\
\hline 1 & 5,5 & 2,289 & 4,773 & 16,963 & 71,915 & 1442,8 & 3,00 & 480,94 \\
\hline 2 & 5,5 & 288 & 4,814 & 17,000 & 71,73 & 1130,9 & 3,05 & 370,78 \\
\hline 3 & 5,5 & 2,275 & 5,355 & 17,471 & 69,397 & 12565 & 3,10 & 405,33 \\
\hline \multicolumn{2}{|c|}{ Ratarata } & 2,284 & 4,981 & 17,145 & 71,014 & 1276,733 & 3,05 & 419,02 \\
\hline 1 & 6,0 & 2,297 & 3,768 & 17,114 & 78,033 & 1574 & 3,13 & 502,87 \\
\hline 2 & 6,0 & 2,278 & 4,564 & 17,800 & 74,407 & 1256,5 & 3,20 & 392,67 \\
\hline 3 & 6,0 & 2,289 & 4,103 & 17,403 & 76,472 & 1508,4 & 3,23 & 466,99 \\
\hline \multicolumn{2}{|c|}{ Rata-rata } & 2,288 & 4,145 & 17,439 & 76,304 & 1446,300 & 3,19 & 454,18 \\
\hline 1 & 6,5 & 2,297 & 3,096 & 17,555 & 82,413 & 1311,6 & 3,25 & 403,58 \\
\hline 2 & 6,5 & 2,274 & 4,066 & 18,380 & 77,924 & 1319,4 & 3,28 & 402,24 \\
\hline 3 & 6,5 & 2,275 & 4,024 & 18,345 & 78,11 & 1382,2 & 3,30 & 418,85 \\
\hline \multicolumn{2}{|c|}{ Rata-rata } & 2,282 & 3,729 & 18,193 & 79,482 & 1337,7 & 3,28 & 408,22 \\
\hline
\end{tabular}

Sumber: Hasil Pengujian, 2019

\section{G. Grafik Pengujian Marshall}

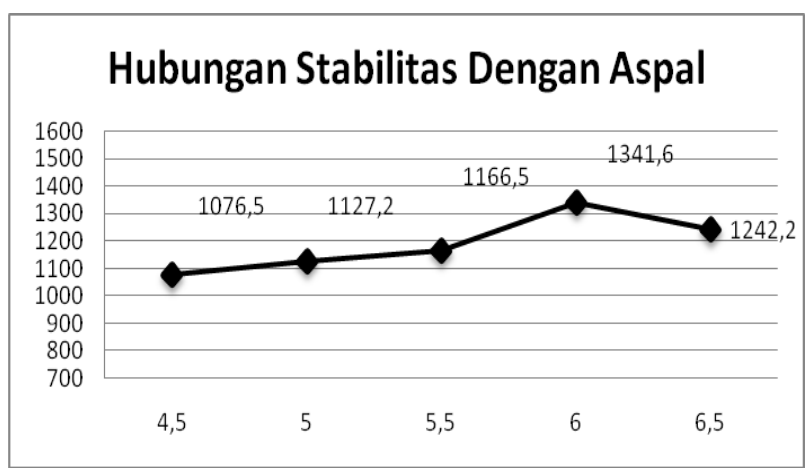

Nilai grafik stabilitas marshall dengan variasi kadar $4,5 \%, 5 \%, 5,5 \%, 6 \%$ dan $6,5 \%$ aspal memiliki nilai stabilitas yang memenuhi spesifikasi yaitu min $800 \mathrm{~kg}$.

\section{H. Pengujian Flow (Kelelehan)}

Nilai grafik flow dengan kadar 4,5\%, 5\%, 5,5\%, 6\%, dan $6,5 \%$ aspal memenuhi nilai spesifikasi yaitu Min 2, $\operatorname{Max} 4$.

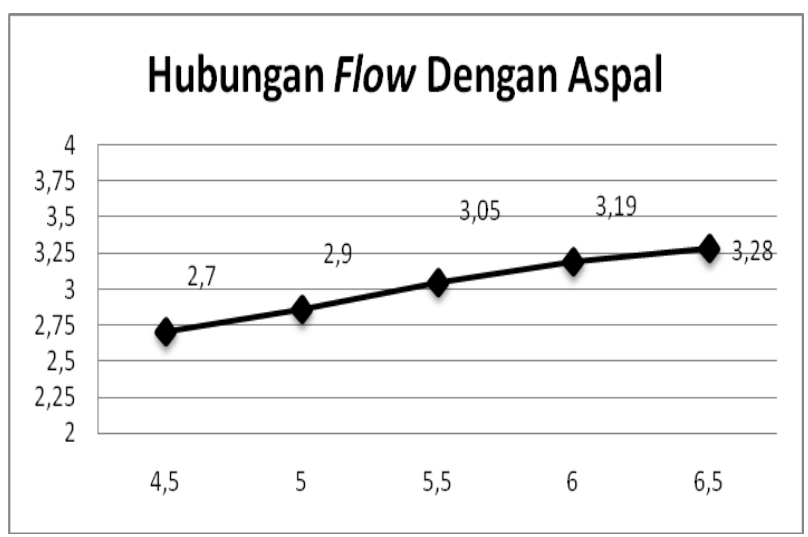


I. Pengujian VIM (Void In The Compacted Mixture)

Nilai grafik VIM dengan kadar 4,5\%, 5\%, 5,5\%, 6\%, dan $6,5 \%$ aspal memenuhi nilai spesifikasi yaitu antara $3 \%-5 \%$.

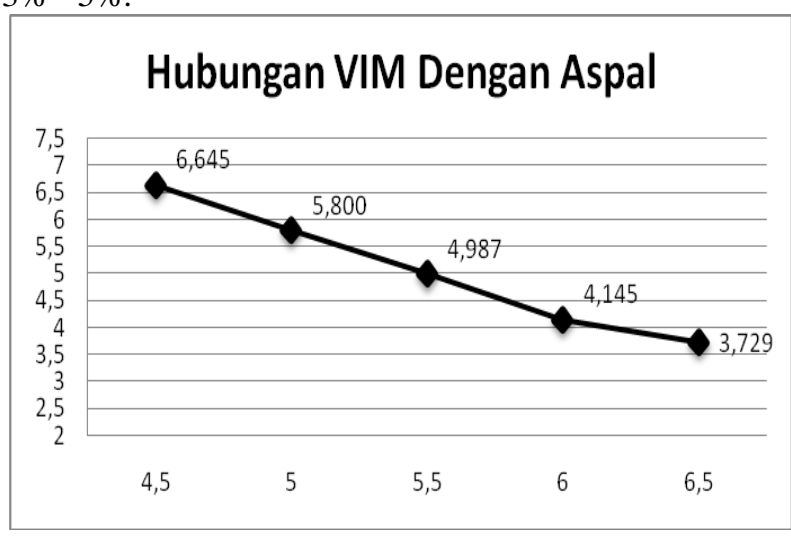

J. Pengujian VMA (Void In The Mineral Agregat)

Nilai grafik VMA menunjukkan setiap benda uji dengan variasi kadar 4,5\%, 5\%, 5,5\%, 6\%, dan $6,5 \%$ kadar memenuhi nilai spesifikasi.

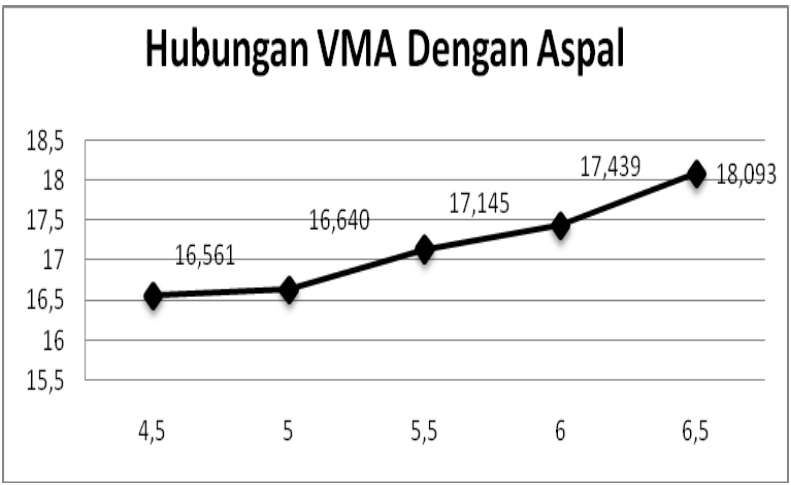

\section{K. Pengujian $V F B$}

Nilai frafik VFB dengan lima variasi kadar 4,5\%, $5 \%, 5,5 \%, 6 \%$, dan $6,5 \%$ memenuhi nilai spesifikasi yaitu Min $65 \%$.

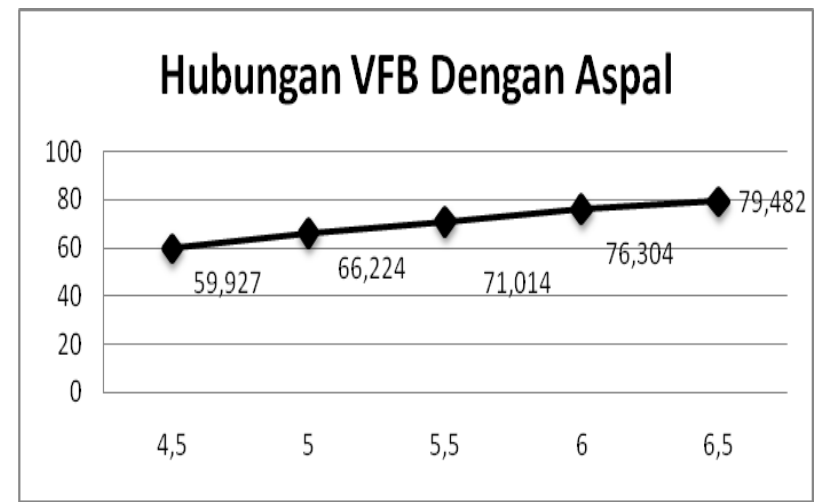

Grafik hasil pengujian marshall aspal konvensional dengan kondisi seperti pada gambar berikut.

\begin{tabular}{|c|c|c|c|c|c|c|}
\hline \multirow{2}{*}{ Variabel } & \multicolumn{5}{|c|}{ Kadar Aspal } \\
\hline & 4,5 & 5,0 & 5,5 & 6,0 & 6,5 \\
\hline \multirow{3}{*}{ Stabilitas } & & & & & & \\
\hline & & & & & & \\
\hline \multirow{2}{*}{ Flow } & & & & & & \\
\hline & & & & & & \\
\hline \multirow{2}{*}{ VMA } & & & & & & \\
\hline & & & & & & \\
\hline & & & & & & \\
\hline \multirow{2}{*}{ VIM } & & & & & & \\
\hline \multirow{2}{*}{ VFA } & & & & & & \\
\hline & & & & & & \\
\hline & & & & & & \\
\hline
\end{tabular}

L. Komposisi Campuran Aspal dengan Arang Kelapa Sawit.

Grafik menunjukkan gradasi batas atas dan gradasi batas bawah memenuhi spesifikasi Umum Bina Marga Revisi 3, dapat digunakan sebagai campuran aspal laston AC-WC.

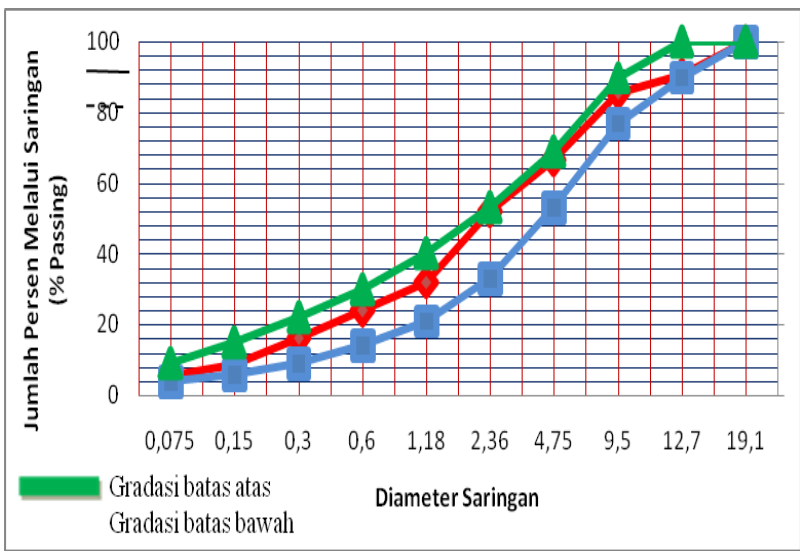

M. Pengujian Marshall Test Aspal dengan Filler Arang Cangkang Kelapa Sawit.

Pengujian Stabilitas

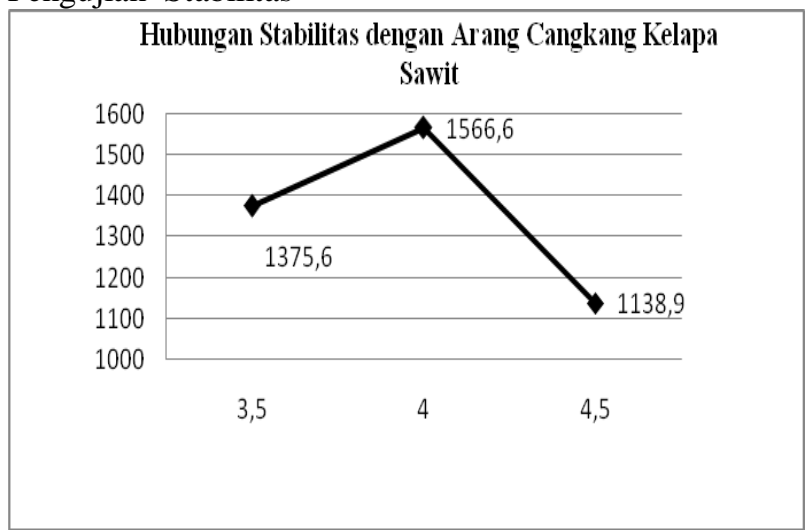

Grafik diatas menunjukkan nilai stabilitas marshall dengan 3 variasi kadar arang cangkang kelapa sawit memiliki nilai stabilitas yang tinggi dari spesifikasi yaitu min $800 \mathrm{~kg}$ hal ini disebabkan oleh kadar aspal yang 
tinggi yaitu 6\% karenakan nilai stabilitas akan meningkat jika kadar aspal bertambah dan setelah mencapai nilai maksimum, stabilitas akan menurun.

\section{N. Pengujian Flow (Kelelehan)}

Hubungan Fllow dengan Arang Cangkang Kelapa Sawit

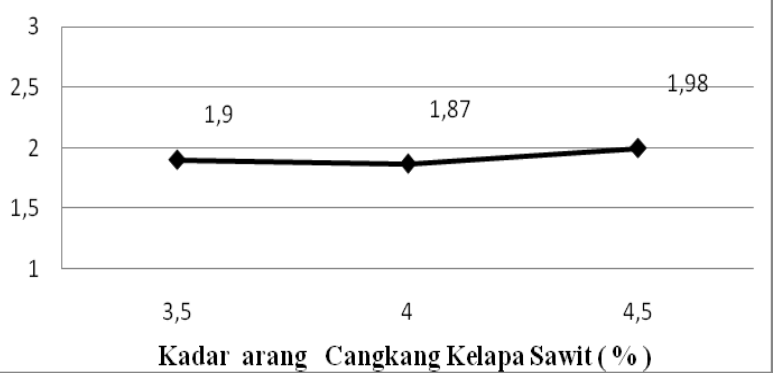

Dari hasil grafik terlihat terjadi penurunan hubungan fllow dengan arang cangkang kelapa sawit pada kadar $3,5 \%$ ke $4 \%$ sedangkan ke 4,5\% terjadi kenaikan. Nilai pengujian flow (kelelehan) marshall dengan kadar arang cangkang kelapa sawit $3,5 \%, 4 \%$ dan $4,5 \%$ tidak memenuhi spesifikasi hal ini disebabkan oleh kadar filler yang dipakai terlalu tinggi sehingga membuat nilai flow menjadi kecil.

\section{O. Pengujian VIM (Void in the Compacted Mixture)}

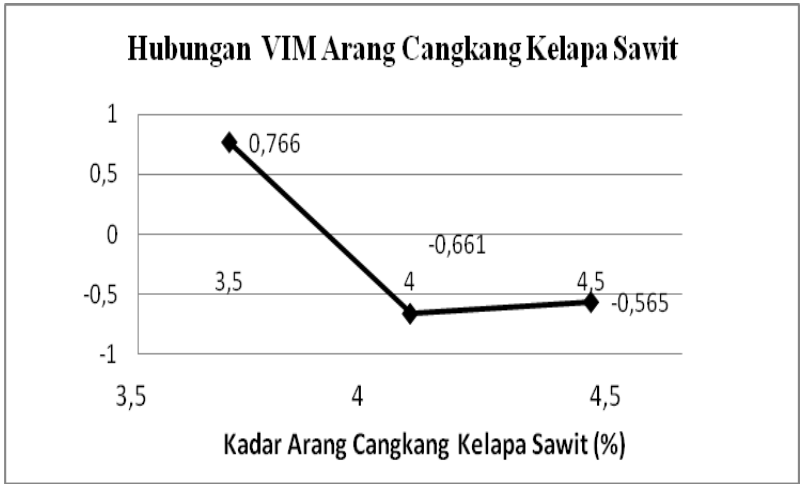

Grafik diatas menunjukkan bahwa penurunan hubungan VIM arang cangkang kelapa sawit terjadi pada kadar $3,5 \%$ ke $4 \%$ sedangkan $4 \%$ ke $4,5 \%$ terjadi sedikit kenaikan. Nilai VIM dari tiga variasi kadar arang cangkang kelapa sawit $3,5 \%, 4 \%$ dan $4,5 \%$ tidak memenuhi nilai yang diizinkan yaitu 03-05 hal ini disebabkan oleh kadar aspal dan filler terlalu tinggi sehinggan menyebabkan volumen rongga dalam campuran semakin berkurang atau niali VIM kecil.

\section{P. Pengujian VMA (Void In The Mineral Agregat)}

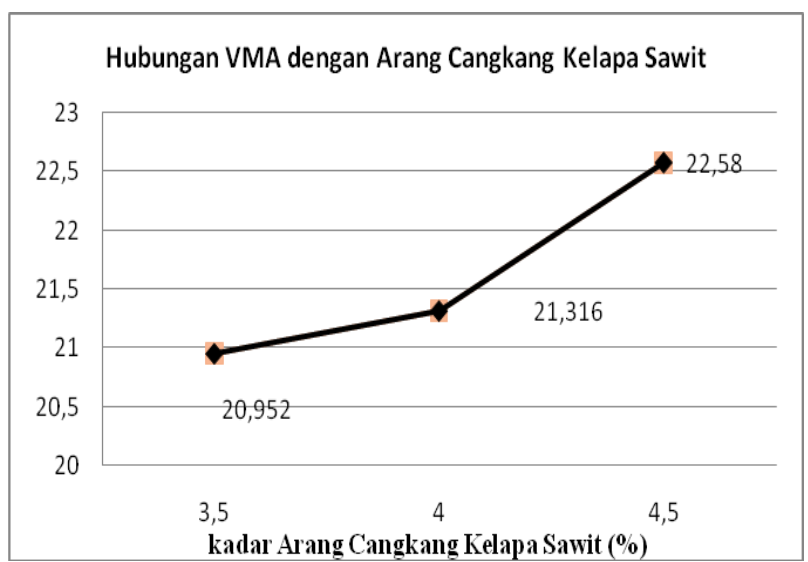

Grafik hubungan VMA dengan arang cangkang kelapa sawit dapat dilihat bahwa peningkatan VMA terjadi pada kadar $3,5 \%$ ke $4 \%$ dan $4 \%$ ke $4,5 \%$. Dri Grafik VMA menunjukkan bahwa setiap benda uji kadar arang 3,5\% sampai dengan kadar aspal 4,5\% memiliki VMA yang diizinkan yaitu Min $15 \%$.

\section{Q. Pengujian VFB}

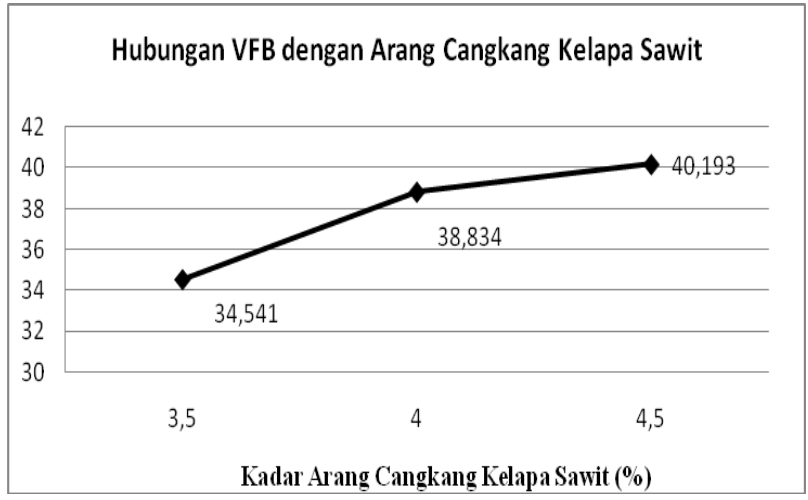

Pada grafik hubungan VFB dengan arang cangkang kelapa sawit terjadi peningkatan yang cukup jauh pada kadar 3,5\% ke 4\% sedangkan dari 4\% ke 4,5\% peningkatan yang terjadi tidak terlalu signifikan. Dari hasil grafik diatas nilai 3 variasi kadar arang cangkang kelapa sawit yaitu 3,5\% - 4,5\% tidak memenuhi nilai VFB yang diizinkan yaitu Min $65 \%$. Hal ini dikarenakan rongga yang terisi aspal hanya sedikit.

R. Perbandingan Hasil Marshall Test Aspal Konvensional Dan Marshal Test Aspal Dengan Filler Arang Cangkang Kelapa Sawit.

\begin{tabular}{|c|c|c|c|c|c|c|}
\hline No & Parameter & Spesifikasi & $\begin{array}{c}\text { Aspal } \\
\text { Konvensional }\end{array}$ & $\begin{array}{c}\text { Aspal + } \\
\text { Arang } \\
\mathbf{3 , 5 \%}\end{array}$ & $\begin{array}{c}\text { Aspal + } \\
\text { Arang 4\% }\end{array}$ & $\begin{array}{c}\text { Aspal+ } \\
\text { Arang } \\
\mathbf{4 , 5 \%}\end{array}$ \\
\hline 1 & Stabilitas & $\geq 800 \mathrm{~kg} / \mathrm{mm}$ & 1341,6 & 1375,6 & 1566,6 & 1138,9 \\
\hline 2 & Flow & $\geq 2,0-4,0 \mathrm{~mm}$ & 3,19 & 1,9 & 1,87 & 1,98 \\
\hline 3 & VIM & $\geq 3,0-5,0 \%$ & 4,145 & 0,766 & $-0,661$ & $-0,565$ \\
\hline 4 & VMA & $\geq 15 \%$ & 17,439 & 20,95 & 21,31 & 22,58 \\
\hline 5 & VFB & $\geq 65 \%$ & 76,304 & 34,541 & 38,834 & 40,193 \\
\hline
\end{tabular}

Hasil Marshall test nilai stabilitas untuk aspal dengan arang cangkang kelapa sawit, dari hasil pembacaan langsung pada alat Marshall test dengan kadar arang 
$3,5 \%(1375,6), 4 \%(1566,6), 4,5 \%(1138,9)$ diperoleh nilai lebih besar dari batas spesifikasi $\geq 800 \mathrm{~kg} / \mathrm{mm}$. Hal ini menunjukkan nilai stabilitas terlalu tinggi yang akan menghasilkan perkerasan terlalu kaku sehingga keawetannya berkurang.

Sementara nilai flow aspal dengan arang cangkang kelapa sawit hasilnya tidak memenuhi batas spesifikasi $\geq 2,0-4,0 \mathrm{~mm}$, hal ini disebabkan karena kadar filler yang digunakan terlalu tinggi yang berakibat hasil nilai flow menjadi kecil, sehingga campuran yang memiliki kelelehan (flow) yang rendah akan lebih kaku dan cenderung mengalami retak dini pada usia pelayanannya. Nilai VIM menujukkan hasil menjadi kecil dengan penambahan arang cangkang kelapa sawit dengan sampel 3,5\%, 4\%, 4,5\% dimana nilai kurang dari $1 \%$ sehingga tidak memenuhi spesifikasi dengan rentang nilai $\geq 3,0-5,0 \%$.

Semakin berkurang atau nilai VIM menjadi kecil maka rongga udara dalam campuran yang terlalu kecil dapat menimbulkan bleeding. Bleeding disebabkan oleh penurunan kadar aspal. Semakin kecil rongga udara maka campuran beraspal akan makin kedap terhadap air, tetapi udara tidak dapat masuk kedalam lapisan beraspal sehingga aspal menjadi rapuh dan getas. Nilai VIM sangat penting pada campuran perkerasan karena berpengaruh dengan stabilitas, ketahanan dan kekedapan terhadap air pada lapisan perkerasan jalan.

Sedangkan hasil nilai VFB untuk kadar aspal dan arang 3,5\% didapat 34,541, kadar 4\% $(38,834)$, kadar $4,5 \%(40,193)$ lebih rendah dibandingkan dengan hasil aspal konvensional sebesar 76,304. Hasil VFB untuk kadar aspal dan arang tidak memenuhi spesifikasi dan dapat menyebabkan rongga yang terisi aspal hanya sedikit, yang akan mengakibatkan campuran bersifat porous dan mudah teroksidasi.

Hasil pemeriksaan menunjukkan pengaruh kadar aspal ditambah arang mengakibatkan nilai VMA mengalami kenaikan dari Aspal konvensional. Hal ini disebabkan rongga dalam campuran lebih kecil, menyebabkan kerapatan campuran meningkat, yang berpengaruh pada daya ikat agregat dengan aspal lebih baik, kondisi ini menunjukkan bahwa hasil nilai VMA memenuhi diatas batas spesifikasi campuran yaitu $15 \%$.

\section{Kesimpulan}

Dari hasil penelitian yang telah dilakukanvdan analisa perhitungan pada campuran laston AC-WC, dapat ditarik kesimpulan sebagai berikut

1. Penambahan arang cangkang kelapa sawit sebagai filler kedalam campuran laston menunjukkan meningkatnya stabilitas dengan Nilai 1566,6 $\mathrm{kg} / \mathrm{mm}$ dibanding dengan aspal konvensional dengan hasil nilai $1341,6 \mathrm{~kg} / \mathrm{mm}$, serta memenuhi batas spesifikasi $\geq \mathrm{kg} / \mathrm{mm}$.

2. Penggunaan aspal dengan filler arang cangkang kelapa sawit mendapatkan nilai nilai VIM, flow, FVB tidak memenuhi batas spesifikasi sehingga tidak dapat digunakan untuk bahan pengganti filler pada campuran aspal beton. Hal ini dikarenakan jika nilai flow rendah maka campuran sangat berpontensi mengalami keretakan, begitu juga dengan nilai VIM , bila terlalu kecil maka akan menyebabkan terjadinya kerusakan rongga didalam campuran sehingga membuat aspal menjaadi kedap air, rapuh dan getas. Dan untuk nilai FVB yang rendah akan mengakibatkan campuran bersifat porous dan mudah teroksidasi.

\section{Daftar Pustaka}

Modul, 2010 "Pengendalian Mutu Pekerjaan Aspal dan Agregat .Spesifikasi” Devisi 6 Perkerasan Aspal, Departemen Pekerjaan Umum.

Susilo, Joko, 2010 "Pengaruh Variasi Suhu Pencampuran Dan Pemadatan Campuran Beraspal Panas Menggunakan Aspal Retona Blend 5". Riau

Kementrian Pekerjaan Umum. 2010. "Spesifikasi Umum Bina Marga Revisi3”. Pekerjaan Umum, Jakarta.

Fannisa, Wahyudi. 2010. "Perencanaan Campuran Aspal Beton Dengan Menggunakan Filler Kapur Padam", Undip Semarang

Balai Bahan dan Perkerasan Jalan, 2009. "Pusat penelitian dan Pengembangan Jalan dan Jembatan" Departemen Pekerjaan Umum. Jakarta

SNI 1970-2008. 2008. Tentang "Uji Berat Jenis dan Penyerapan Agregat Halus". Jakarta: Departemen Pekerjaan Umum.

Hardiyatmo,H.C., 2007. "Pemeliharaan Jalan Raya", Gadjah Mada University Press, Yogyakarta).

Setiawan AD, 2003, Pengaruh Penuaan dan Lama Perendaman Terhadap Durabilitas Campuran Asphalt Concrete Wearing Course (AC-WC).

Sukirman, S.,.2003. Beton Aspal Campuran Panas, Granit, Jakarta.

Badan Standarisasi Nasional (BSN),1991, "Metode Pengujian Kelekatan Agregat Terhadap Aspal”, SNI 03-2439-1991, Jakarta.

Badan Standarisasi Nasional (BSN), 1991, "Metode Pengujian Campuran Aspal Dengan Alat Marshall', SNI 06-2489-1991, Jakarta. 